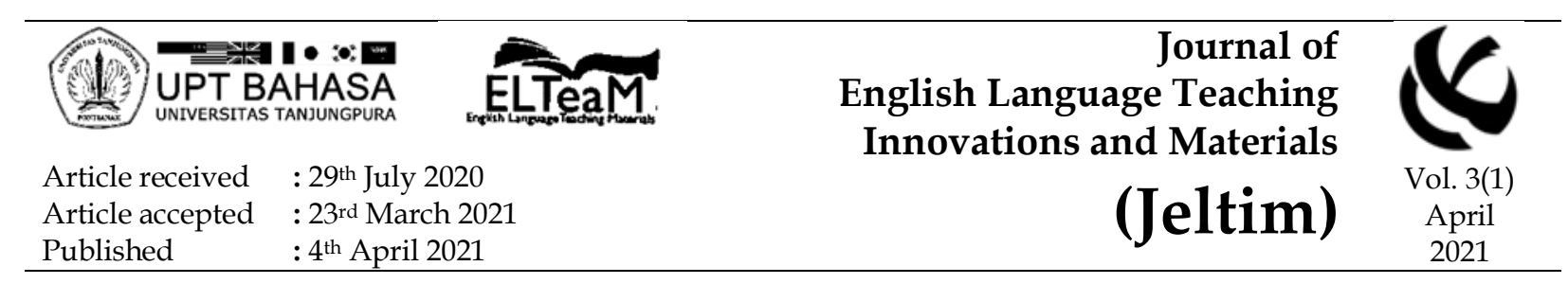

\title{
Developing HoPALM as teaching materials for secondary school students
}

\author{
Asih Sauramanda ${ }^{1}$, Majid Wajdi ${ }^{2}$, Iwan Supardi ${ }^{3}$ \\ ${ }^{1}$ Master's Study Program of English Language Education Teacher Training and Education \\ Faculty, Tanjungpura University, Pontianak, Indonesia \\ dias.sauramanda@gmail.com \\ ${ }^{2} J u r u s a n A d m i n i s t r a s i N i a g a$, PoliteknikNegeri Bali, Bali, Indonesia \\ wajdi@pnb..ac.id \\ ${ }^{3}$ Master's Study Program of English Language Education Teacher Training and Education \\ Faculty, Tanjungpura University, Pontianak, Indonesia \\ iwan.supardi26@gmail.com \\ DOI: http://dx.doi.org/10.26418/jeltim.v3i1.41696
}

\begin{abstract}
This research was aimed to develop a product named HoPALM (Hot Potatoes Assisted Listening Material) for secondary high school students. This research applied research development and ADDIE procedure. On the analysis stage, the researchers found the fundamental problems and needs of the students as well as the opportunity as the background for developing HoPALM. On the designing and developing stage, the researchers collected the sources needed and developed HoPALM by using the features through hot potatoes program. After the product was assessed by the material content and the multimedia experts, HoPALM was considered valid and applicable to use. The researchers implemented the product to the two school targets, SMA Negeri 1 and 2 Sungai Kakap. According to 208 students of the two schools, as many as 156 students or $75 \%$ of them felt more motivated and preferred to learn English. As many as 123 students or $59.1 \%$ of them were able to overcome difficulties encountered. 120 students or $57.7 \%$ admitted that their listening ability increased. Furthermore, although not spontaneously, as many as 196 students or $95.6 \%$, confessed being able to understand what they were listening to, especially if there were images in that section. Most importantly, as many as 120 students or $57.7 \%$ were more motivated in learning English.
\end{abstract}

Keywords: HoPALM, Hot Potatoes, Listening, Development Research

Journal of English Language Teaching Innovations and Materials (Jeltim), 3(1), 48-60

Copyright ( 2021 by Jeltim, e-ISSN 2657-1617 
How to cite this paper: Sauramanda, A., Wajdi, M., \& Supardi, I. (2021). Developing HoPALM as teaching materials for secondary school students. Journal of English Language Teaching Innovations and Materials (Jeltim), 3(1), pages. DOI: http://dx.doi.org/10.26418/jeltim.v3i1.41696

Technological developments lead to change in work, in the organization of work, and in competency requirement. The development of science, art and technology today has brought rapid changes in aspects of human life. The developments have changed people's paradigm in searching for and getting information more easily. Based on that basis, it is undeniable that technology is also one of the supporting facilities in education, in order to achieve its goals. Listening is one of English language skills which need to be mastered to communicate properly to others. Listening as one of receptive processes in learning and acquiring language through bottom-up or top-down process (Savile-Troike, 2006). In many students' tests, listening section is considered as one of the most difficult parts such as in the national examination and TOEFL (Test of English as a Foreign Language). Furthermore, as EFL learners, the students need to master the listening skill in order to achieve English mastery properly. The listening class needs an authentic material as in its implementation. As stated by Herod (2002), authentic learning 'materials and activities' are designed to imitate the real world situations. Because an authentic material could bring the most appropriate and natural context and situation in the classroom.

Amongst many programs available, hot potatoes is quite useful and practical. Some researchers reviewed hot potatoes for its useful benefits in language teaching. Pariyanto and Herawati (2020) proved that hot potatoes were effective in teaching descriptive text. Vargas and Monge (2014) believed that hot potatoes is prominent since it is user friendly, customizable, and compatible with various operating systems; it even comes with its own tutorials and exercise samples for users, in this case teachers and students, to start learning to develop activities with it. Soleimani and Raeesi (2015) reviewed and highlighted the positive aspects of hot potatoes, which include quick and immediate feedback it provides to every single question, a hint of the test items, posting and displaying test result on the web, and the audio-visual files integrated capabilities. Soleimani \& Sadeghi (2015) pointed out hot potatoes was designed to help teachers develop interactive web-based activities that students could easily access. Hot potatoes generates six different types of web-based exercises that can be used individually or in combination with other exercises. Students may also correct or edit their work based on the hints and suggestions set up in advance by the teacher.

The purpose of hot potatoes is to enable teachers to create teaching exercises which can be delivered to any interned-connected computer equipped with a browser. It uses HTML and JavaScript to implement their interactivity. Even

Journal of English Language Teaching Innovations and Materials (Jeltim), 3(1), 48-60 Copyright ( 2021 by Jeltim, e-ISSN 2657-1617 
though this program is operatively with the internet access, for the outskirt schools area, we can operate the program in offline mode.

This program helped the teachers to have better teaching strategies and to improve English teacher's performance. Teachers can use hot potatoes application to support their teaching, especially in their instruments for testing the students (Syamsudin \& Kurniawati, 2016). This program can also enhance students' listening, speaking, reading and writing skills. The teacher can put many kinds of texts, images, graphics, even audios and videos. This application can be used individually or in a form of group. When students have test using this program individually, teacher can measure students' competence individually.

There are some reasons of using hot potatoes. First, there are six features in hot potatoes can be used by the writer to conduct the learning media. It is hoped that students will be interested in it. They would study as well as play a game and unconsciously acquire the knowledge. Second, hot potatoes could be launched both in online and offline modes. So if there is a school which is out of internet connection and lack of facilities such as language laboratory, they still could operate the hot potatoes in offline mode and facilitated with a projector and a sound system (Yavuz, 2011). Third, it could not avoid that, listening material should be authentic. Hot potatoes can cover that, the creator can put pictures, images, photos, audio, and videos to the application and formulate it into an authentic listening material. The listening learning will be more successful if the students can study both in audio and visual forms and the communicative competence can be achieved (Mallapiang, 2014). Therefore, the researchers developed HoPALM as teaching materials to provide students an authentic listening material, which refer to audio recordings of a discourse or conversations that were spontaneously generated by the native speakers.

\section{METHOD}

The approach of this research is RD (Research Development). This research dealt with the media development, which was developed through hot potatoes program. It adopted the ADDIE procedure, which was intended to guide the researchers in conducting both research and product from the very first step to the evaluation of the product. There are some steps to follow in doing a research development. Those steps are known as ADDIE, which stands for Analyze, Design, Develop, Implement, and Evaluate (Branch, 2009). Below is the figure of the procedure of research which was conducted by the researchers. 
Figure 1. The Procedures of the Research

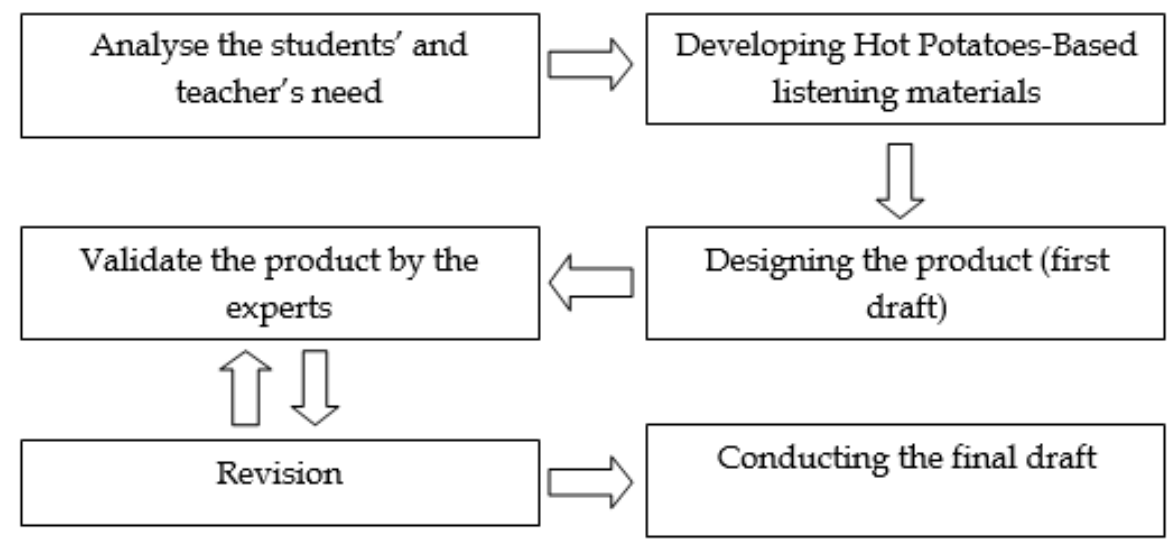

The locations of this research are SMA Negeri 1 Sungai Kakap, and SMA Negeri 2 Sungai Kakap. These two schools were chosen because they can represent schools which had lack of listening materials. Based on the survey, those two schools have no language laboratory, less in listening audio material, and implementing listening materials by using one speaker/sound system in front of the classroom or sometimes a monologue or conversation which was only read by the teacher.

The researchers started analyzing students' and school's needs, followed by designing and developing HoPALM. Before implementing the product, the researchers validated HoPALM to the experts. When the quality of the product was still low, the researchers must revise the product and re-validate to the experts until the product was considered to be valid and to have high quality, then, based on those steps the researchers composed the final draft of the product. The designing phase was to verify the desired performances and appropriate testing methods (Branch, 2009). In this phase, the researchers prepared the material sources which suits for secondary high school students, completed it with exercises and tests. The most important thing, the teacher/ designer should pay attention to the limitation of resources and facilities of the school. Developing stage, after all the preparations were done, the researchers developed the framework. Following the principles, procedures, also the criteria of good material will support the designer in developing the materials. On the implementation stage, after the materials are ready, teacher can implement it to the students. With all of considerations, the materials have been developed can facilitate the learning process effectively. There are two things should be prepared in implementation phase according to (Branch, 2009), preparing the teacher and preparing the students. Preparing the teacher means that they are ready to facilitate the learning process. If the teacher was considered less capable, the researchers simultaneously guide the teacher in using HoPALM. Preparing the students means, they are prepared to receive information that must be wellunderstood, and they can be responsible for their listening skills, and can learn

Journal of English Language Teaching Innovations and Materials (Jeltim), 3(1), 48-60 Copyright ( 2021 by Jeltim, e-ISSN 2657-1617 
independently outside the classroom. Evaluation stage is considered as a procedure that stimulates and improves learning materials to establish their value (Gafoor, 2013). In the evaluation section, the researcher divided into two parts. Firstly, evaluation of the materials based on experts and secondly, prepare the evaluation based on students' perspective.

\section{FINDINGS}

The students' and teachers' analysis were done at two school targets. Based on the result of the interview, it was found that most of the students still got difficulties in learning English especially listening skill. They really need a supplementary material that are not available at school for learning. These findings were also admitted by the teachers, that the students really need special listening materials to make them more motivated in learning and to improve their listening skill. Based on the survey on some bookstores in Pontianak, it was found that all the bookstores provided English textbooks, but there was no book was provided with the audio cassettes. This result of analysis became the fundamental reason in developing the listening material.

In developing this product, researchers have compiled a form of product design, in order to represent all the needs, the weaknesses, and the objectives of this product. In designing the HoPALM, the researchers have conducted three steps. First, identifying the instructional goal (Dick et al., 2005) or the objective of the product. Second, implementing the subject matter and personal experience and third designing product by selecting the contents/ words and audio, and effective strategies in a logical sequence (Branch, 2009).

The first step was starting with identifying the instructional goal. Based on the analysis process, it was concluded that the main goal of this product is to help and support for the teachers and students in the listening class. As strengthened by Rost in (Yildirim \& Yildirim, 2016) that listening is vital in the language classroom because it provides input for the learner. Without understanding input at the right level, any learning simply cannot begin. The instruction would be expected to cover all the needs and the limitations for students and teachers in case of facilitation, especially for rural school in Kubu Raya specifically and Kalimantan Barat in general. Besides, the accustomed to listening to native speakers' sound, it will be easier for them when facing listening sections in each test. The product being developed was aimed at being easy to understand, and easy to carry so students can learn independently. This phase requires logical and creative thinking. It requires the ability to get inside the mind of the students. There are a few things that the researchers should consider as beginning to create the steps to help build a product which suits the analysis findings. In this phase, the researchers designed the product based on what students like to learn, the students' personality, the shortcoming of the school in providing the listening class and making as easy product as possible

Journal of English Language Teaching Innovations and Materials (Jeltim), 3(1), 48-60 Copyright ( 2021 by Jeltim, e-ISSN 2657-1617 
which will be used by teachers and students. Those aspects were done in the need analysis phase.

Second, in developing the instructional design, the researchers implemented the subject matter and their personal experiences. Hot potatoes was considered as an easy application to conduct, both words/images and sounds/audios could be applied on the same page. Somehow, the product could be launched in online mode. The researchers had to know the structure of the discipline which could provide cognitive roadmaps to guide the students in using the product.

In the third was the suitable selective words/images and audio as well as the strategy and put in the logical sequence from easy to difficult. The point was, the researchers made a warm product as possible. So that, it will be easily used by the teachers and students. The selection of clear audio voice content will give the students a clearer impression while listening. The combination of pictures and audios can attract the students' attention in learning listening as well. The listening materials and quizzes displays were designed in such a way they look like in listening test. The feedback and score are immediately and directly given after the students finish the quiz. The most important thing, in order to achieve the learning objectives of listening as explained previously, the researchers designed an interest, meaningful, and easy hot potatoes based listening material. Collecting as much as appropriate contents were needed which had been selected. Then posted it in a developing folder.

On the first step, after opening the app, the researcher or the creator may choose one of the features are provided on hot potatoes, depends on what the creator needs for the students. In this case, most widely used by the researchers is JQuiz. The second step, the researchers started in making the quiz, first, wrote the title of the quiz, then for the question number 1 , before writing down the question, the researchers put the codes of listening audio. The selection of the appropriate code is very important, because not all PCs have the same type of audio player software. Then, the writing of the code must be as accurate as possible, the name of the audio files should be correct, because if there is a slight error in writing the code, audio listening will not be played. The researchers suggested that to create the audio file's name as easy as possible. Then, the researchers wrote down the answer choices of the question and marked the correct answer choice. After all things backed up, the researcher save the file. In saving the files, the researchers remind that to save all the file source in one folder and might not be separated.

The third step, researchers can already see the results, the appearance will be an HTML page, but offline. They clicked on the blue export mark among the options, and returned to save the file, for ensuring that the artificial file and the resulting file were stored in the same folder. Remember that the name of the file might not be separated or spaced. The researchers directly clicked on the play button to hear the listening audio, and tried to answer to make sure the answer

Journal of English Language Teaching Innovations and Materials (Jeltim), 3(1), 48-60 Copyright ( 2021 by Jeltim, e-ISSN 2657-1617 
is correct. Moreover, the creator might do the same steps as above in creating other quizzes. In order to make the user easy to use the product, the researchers grouped the files into some folders based on its categories.

As for the conclusions of the implementation process, first, the focus of HoPALM was more on "stabilizing" learning resources that are less specifically listening, for those schools that are indeed lacking in facilities. Second, increasing students' interest in learning in English, which was based on the fact that students become lazy to listen because they do not understand what they are listening to. As for the improvement of students' listening skills, it is not the main focus, but an additional "reward" if students practice in both classroom learning and independent learning.

As it was believed, students could use this product independently, the researchers invited several students to work directly without being given instructions and direction. Nine out of 12 students could directly use HoPALM. The three other students asked at the beginning, but the rest could use it independently. On the teacher's side, it ensured that teacher was able to use HoPALM in teaching listening, it was proved when the teacher came along with the researchers while implementing HoPALM to the students. One of the researchers had experienced, when she showed one feature of HoPALM in front of the English teacher community, the teachers got excited and really motivated to learn how to use the same kind of teaching media hot potatoes based. The final phase of any process is that of evaluation. This is the process to determine whether the instruction is sufficient or not and to measure the learning objectives and the students' need. To determine the validity of HoPALM, the researchers completed with one of the lecturers in Universitas Tanjungpura Pontianak. On this aspect, the validator assumed that the developed product was applicable but with some revisions and suggestions. On this stage, six out of 11 points were considered qualified. The other 5 points needed to be revised.

Furthermore, the validator stated that the material was still not enough and needed adding. The product was categorized as applicable, but it needed some revisions based on the validator's suggestion. Then, researchers put more materials on the product. The researchers conducted more quizzes and exercises which were related to the national examination.

\begin{tabular}{llcc} 
No. & Content Aspects & Yes & No \\
\hline 1. & $\begin{array}{l}\text { Deliver content meets the curriculum/ syllabus of } \\
\text { Secondary High Schools }\end{array}$ & $\sqrt{ }$ \\
\hline 2. & $\begin{array}{l}\text { Provide learning activities that cannot be done through } \\
\text { print-based media }\end{array}$ & $\sqrt{ }$ \\
\hline 3. & $\begin{array}{l}\text { Direct the students to the literacy skill (directing } \\
\text { students to find deeper in order to understand the } \\
\text { information being heard) }\end{array}$ & $\sqrt{ }$ \\
\hline 4. & Provide the quizzes or exercises & $\sqrt{ }$
\end{tabular}


5. Provide the instruction for the students

6. Provide students' interaction directly to the quiz

7. Provide the feedback directly

8. Pictures suit to the audio content of the activities

9. Provide scores or results directly after the session

10. Provide systematic arrangement of activities

11. Provide wider information access to students' Higher

Order Thinking (HOT) and Lower Order Thinking (LOT)

Table 1. Instruments for Content Expert Validation

The indicators of content validity, by the expert were considered to have fulfilled the requirements. It was categorized as applicable and ready to use.

Another step is multimedia validation. HoPALM was categorized as applicable, but still some revisions were needed in providing the display of the front page. The researchers should make the display clearer, so the students can choose the content materials easily. The audio of the media needed to be classified, the questions, the texts or the script must be correctly written, and the hint/ clue should not directly provide the answer.

\begin{tabular}{|c|c|c|c|}
\hline No. & Multimedia Aspects & Yes & No \\
\hline 1. & Provide clear display of front page & $\sqrt{ }$ & \\
\hline 2. & Provide clear display of content & $\sqrt{ }$ & \\
\hline 3. & Provide appropriate size and color of the text & $\sqrt{ }$ & \\
\hline 4. & Provide attractive pictures & $\sqrt{ }$ & \\
\hline 5. & Provide clear audio content & $\sqrt{ }$ & \\
\hline 6. & Icon and numbering are clear and understandable & $\sqrt{ }$ & \\
\hline 7. & Provide a spacious layout & $\sqrt{ }$ & \\
\hline 8. & Provide an arrangement quiz/exercise page & $\sqrt{ }$ & \\
\hline 9. & Easily accessed by teacher and student & $\sqrt{ }$ & \\
\hline 10. & Provide scores or result directly after the session & $\sqrt{ }$ & \\
\hline
\end{tabular}

As many as 156 students or $75 \%$ of them felt more motivated and preferred learning English after applying HoPALM. The difficulties faced by students also decreased. As many as 123 students or $59.1 \%$ of them were able to overcome difficulties encountered. Despite 85 students or $40.9 \%$ of them still finding listening to be very difficult. This perception was in line with their listening ability. 120 students admitted that their listening ability increased, and 88 students, $42.3 \%$ felt no significant improvement. Furthermore, although not spontaneously, as many as 196 students, 95.6\% confessed being able to 
understand what they listened to, especially if a section was provided with images. Most importantly, as many as 120 students or $57.7 \%$ are more motivated in learning English.

\section{DISCUSSION}

The role of hot potatoes program is a tool used to assist in teaching and learning, and its availability can help to reach the course goals, also it fits to the needs (Brown in Setiawan, 2018). HoPALM was created through hot potatoes program can support and complete the material needed in the field of English education in order to achieve overall learning goals. As the researchers stated in the background that listening and multimedia class could not be separated, learning to listen is not enough just to hear someone reading or dictating, but also to hear native speakers authentically and immediately work on the appropriate form of the question. Authentic listening materials can be useful in many ways. Such materials introduce students to how language is used in the real world and improve their overall language proficiency (Sabet \& Mahsefat, 2012).

As for the needs of students and teachers based on the findings, both need supporting facilities for listening learning. The listening class itself requires extra learning than other English language skills. Listening requires other teaching and learning equipment such as language laboratories or at least the loudspeakers. As well as authentic audio source, if necessary, supported by authentic text and visualization. The learners should get the opportunities to practice by adapting or listening to the real language as authentic texts and materials in their classroom situations to master the foreign language (Dewi, 2018).

Most students find it difficult to learn to listen because in essence, the students are lacking in English vocabulary and knowledge. As stated by Avery and Ehrlich in (Orestes, 2016), that some factors caused poor listening comprehension are the lack of the learners' linguistic competence. This is in line with the facts found that based on the interview process of some students, students admit that the lack of vocabulary is the basis of their weakness in learning English, especially listening.

The facility presented to the students is in addition to overcoming the lack of listening material, complementing and becoming supplementary material that supports the main learning goals, must also be attractive, attract students' attention, authentic, and easy to understand both in terms of content and how to run the facility.

Products that students need are HoPALM that meet the needs, weaknesses, and desires of students. It can increase information access to the learner, provide flexibility to instruction and thereby better serve the individual's learning pace, cognitive style and learning strategies (Gohil \& Parmar, 2018). HoPALM was considered able to supplement the shortcoming of facilities at schools.

Journal of English Language Teaching Innovations and Materials (Jeltim), 3(1), 48-60 Copyright ( 2021 by Jeltim, e-ISSN 2657-1617 
The implementation was done by calling students representative to operate HoPALM. This was aimed to determine whether HoPALM can be used by the students independently. It has been proven that students did not get confused in operating HoPALM, because hot potatoes program is very simple to operate, the feedback and hints were clear, the display was very flexible (Dewanty, 2018). When implementing it in a bigger class, the researchers used a projector and a loudspeaker to perform the display in front of the classroom and sound off the audio. The findings are in line with Tyagi (2013), who advocates techniques to help the students improve the listening skill, minimize external distractions.

Furthermore, the students can use HoPALM in every learning environment. This point was in line with Safer et al., (2015) stated that pictures, interactive quizzes, goals, guidelines, games, and reviews are all included in the hot potatoes-based materials. Students may use it inside or outside the classroom at any time. Furthermore, it was strengthened by Solemani \& Sadeghi (2015) that hot potatoes really fits for distance learning.

\section{CONCLUSSION}

HoPALM was developed according to ADDIE procedures. The procedures were explained one by one, this work aims to contribute to the development of listening teaching and learning materials for secondary high school students.

HoPALM was applicable as the teaching materials for teaching listening. Multimedia is a very complex media that provides the students with complete guidance for learning. HoPALM is a great supplementary listening material which was created offline or online. Creating exercises for learners can give them space to repeatedly practice the target language. HoPALM can give the alternative way in giving tests or assignments to students. It will be interesting to the students and they will not feel stress in doing the test items. In short, HoPALM is suitable choice for teachers who want to make interactive activities. This program can help teachers to create exercises or test items for students.

The researchers recommend HoPALM to be used by the teachers because it is a flexible web-based program, easy-to-use by teachers as well as the students. HoPALM provides interactive language learning activities that may be utilized inside or outside of the classroom or any other learning environment. HoPALM is a valued program for designing and creating on-line and off-line (Fansury et al., 2018).

The researchers suggest for further studies, there will be more English materials to be developed, which can help teachers and students achieve learning goals. 


\section{REFERENCES}

Branch, R. M. (2009). Instructional Design: The ADDIE Approach. New York: Springer.

Dewanty, A. (2018). The Effect of Teaching Reading Using Hot Potatoes Based WenBased Exercise in Improving Junior High School Students' Reading Comprehension Achievement. Yogyakarta: Sanata Dharma University. Retrieved from https://repository.usd.ac.id/32790/2/136332023_full.pdf

Dewi, R. C. (2018). Utilizing Authentic Materials on Students' Listening Comprehension: Does it have Any. Advances in Language and Literary Studies, 9(1), 70-74. http:/ / doi.org/10.7575/aiac.alls.v.9n.1p.70

Dick W, Carey L, James O. (2005). The Systematic Design of Instruction (8th ed). New York: Pearson.

Fansury, A.H, Agreani, A.V, Lutfin, N. (2018). Web-Based Learning Model Using Hot Potatoes Application To Increase Language Students' Achievement. PEOPLE: International Journal of Social Sciences, 4(2), 1546-1553. http://doi.org/10.20319/pijss.2018.42.15461553

Gafoor, K. A. (2013). Types and Phases of Evaluation in Educational Practice. http://doi.org/10.13140/2.1.3801.1680

Gohil, H. M. Parmar, M. (2018). Use of Hot Potatoes Software for Language Teaching and. Online Journal of Multidisciplinary Subjects, 12(3), 374-380. Retrieved from http:/ / www.researchguru.net/volume/Volume\%2012/Issue\%203/RG4 7.pdf

Herod, L. (2002). Adult learning from theory to practice. Heinle \& Heinle Publisher. Heinemann.

Mallapiang, Y. (2014). Using Authentic Material to improve The Students' Listening Skill. Exposure Jurnal Pendidikan Bahasa dan Sastra Inggris, 3(2), 166-177. http://doi.org/10.26618/ejpbi.v3i2.835

Orestes, V. (2016, October). Factors to Consider When Teaching Listening Comprehension in the EFL/ESL Classroom. MAXTESOL Journal, 40(4), 1-6. Retrieved from https://www.mextesol.net/journal/index.php?page=journal\&id_article $=1692$

Rost, M. (2011). Teaching and Researching Listening. London: Pearson.

Sabet, M. K \& Mahsefat, H. (2012). The Impact of Authentic Listening Materials on Elementary EFL. International Journal of Applied Linguistics and English Literature, 1(4), 216-229. http:/ / doi.org/10.7575/ijalel.v.1n.4p.216 
Sadeghi, N., \& Soleimani, H. (2015). A Description and Evaluation of Hot Potatoes Web-authoring Software in Educational Settings. Theory and Practice in language Studies, 5(11), 2407-2415. http://doi.org/10.26618/ejpbi.v3i2.835

Safer, F. Salam, U. Ikhsanudin, I. (2015). Developing Hot Potatoes-Based Materials for SMK. Jurnal Pendidikan dan Pembelajaran Khatulistiwa, 4(1), 114. Retrieved from https://jurnal.untan.ac.id/index.php/jpdpb/article/view/8664

Savile-Troike, M. (2006). Introducing Second Language Acquisition. New York: Cambridge Press.

Setiawan, E. (2016). The Use of Hot Potatoes for Teaching Vocabulary at the Eleventh Grade of SMA Bodhisttva. The Fourth International Conference on Education and Language (pp. 232-241). Bandar Lampung: English Education Study Program of Bandar Lampung University. Retrieved from http://artikel.ubl.ac.id/index.php/icel/article/view/527

Soleimani, H \& Raeesi, A. (2015). Hot Potatoes: The Merits and Demerits. Theory and Practice in Language Studies, 5(6). http:/ / doi.org/10.17507/tpls.0506.24

Syamsudin, S. \& Kurniawati, L. (2016). Using Hot Potatoes Program For Reading Test Instrument In English Teaching Learning Process. IJET (Indonesian Journal of English Teaching), 5(2), 242-254. http:/ / doi.org/10.15642/ijet2.2016.5.2.242-254

Tyagi, B. (2013). Listening : An Important Skill and Its Various Aspects. 1-8. Retrieved from https://www.the-criterion.com/V4/n1/Babita.pdf

Vargas, J. P. Z \& Monge, G. S. (2014). Considering the Use of Hot Potatoes in TEFL, and Learning Styles. Revista de Lenguas Modernas, 309-321.

Retrieved from https:// repositorio.una.ac.cr/bitstream/handle/11056/17178/HotPot.p $\mathrm{df}$ ?sequence $=1 \&$ is Allowed $=\mathrm{y}$

Yavuz, F. (2011). Using Hot Potatoes in Listening Skills. International Journal of Business and Social Science, 2(11), 210-219. http://doi.org/10.30845/ijbss

Yildirim, S., \& Yildirim, Ö. (2016). The Importance of Listening in Language Learning and Listening. Abant İzzet Baysal Üniversitesi Ĕ̆itim Fakültesi Dergisi, 16(4), 2094-2110. Retrieved from https://dergipark.org.tr/tr/download/article-file/291966

\section{Authors' Brief CV}

Asih Sauramanda completed her Bachelor degree in English Language Education at IKIP-PGRI Pontianak and Master's degree in English Language Education at Universitas Tanjungpura. Currently she is an English teacher and a scout coach at SMA Negeri 2 Sungai Kakap, Kabupaten Kubu Raya, Indonesia. 
Majid Wajdi is an English teacher at Politeknik Negeri Bali. He completed his Bachelor degree in English and Literature Program at Faculty of Arts Universitas Udayana, Master degree in Language Education at Universitas Pendidikan Ganesha (Undiksha) Bali, and Ph.D of Linguistic program at Universitas Udayana.

Iwan Supardi is a lecturer at the Faculty of Teacher Training and Education of Universitas Tanjungpura. He completed his Bachelor of Education in ELT at Universitas Tanjungpura, Masters of Applied Linguistics at La Trobe University, and Doctor of Education at Universitas Negeri Yogyakarta. 